Volume 48

Issue 3 Spring 1999: Symposium - Section 1983

Municipal Liability in Civil Rights Litigation

Article 8

\title{
The Scholar Warrior: Visualizing the Kaleidoscope That Is Entity Liability, Negotiating the Terrain and Finding a New Paradigm
}

Clifford S. Zimmerman

Follow this and additional works at: https://via.library.depaul.edu/law-review

\section{Recommended Citation}

Clifford S. Zimmerman, The Scholar Warrior: Visualizing the Kaleidoscope That Is Entity Liability, Negotiating the Terrain and Finding a New Paradigm, 48 DePaul L. Rev. 773 (1999)

Available at: https://via.library.depaul.edu/law-review/vol48/iss3/8

This Commentaries is brought to you for free and open access by the College of Law at Digital Commons@DePaul. It has been accepted for inclusion in DePaul Law Review by an authorized editor of Digital Commons@DePaul. For more information, please contact digitalservices@depaul.edu. 


\title{
THE SCHOLAR WARRIOR: VISUALIZING THE KALEIDOSCOPE THAT IS ENTITY LIABILITY, NEGOTIATING THE TERRAIN AND FINDING A NEW PARADIGM
}

\author{
Clifford S. Zimmerman*
}

Skill is the essence of the Scholar Warrior. Such a person strives to develop a wide variety of talents to a degree greater than even a specialist in a particular field. Poet and boxer. Doctor and swordsman. Musician and knight. ${ }^{1}$

The civil rights lawyer who pursues a claim under 42 U.S.C. $\S 1983^{2}$ against a public entity must epitomize the Scholar Warrior, deftly balancing an ever splintering and multiplying framework of what constitutes public entity liability with the tact, fervor, and energy found in only the greatest of strategists and fighters. Two points in any discussion of municipal liability or Monell $^{3}$ claims, better termed local public entity claims, ${ }^{4}$ are beyond dispute at this stage. First, there are manifold problems with Monell and its progeny. Second, the Supreme Court has increased its interest in addressing this issue in a way other than tinkering with minor aspects as each case is decided.

Our Symposium presenters support each of these conclusions, as well as the need for a new direction in this area to effectuate the goals of the statute. This Essay/Commentary will unify the five presentations with the Scholar Warrior theme while exploring the future direction of public entity liability such that systemic problems are addressed and true reform can be attained.

* Senior Legal Writing Instructor, DePaul University College of Law. (C) 1999 Clifford S. Zimmerman, all rights reserved. Many thanks to the DePaul Law Review for inviting me to participate in this Symposium. My strongest appreciation and thanks extend to Jennifer Jendusa and Kevin Vodak for their excellent research, editing, and footnote work.

1. Deng Ming-Dao, Scholar Warrior: An Introduction to the Tao in Everyday LiFE 10 (1990).

2. 42 U.S.C. $\S 1983$ (1994).

3. Monell v. Department of Soc. Servs., 436 U.S. 658 (1978).

4. Although such claims are typically dubbed "municipal liability" claims, technically the claims can be brought against any public entity, including municipalities, counties, park districts, and school boards. Thus, while many claims are against municipalities, the term is too narrow to accurately reflect the true potential institutional targets. 


\section{The Scholar Warrior and Local Public Entity Claims}

Local public entity claims are brought essentially for one of two reasons: either to pursue a deep pocket that can actually pay the damages awarded to the plaintiff for a violation of constitutional rights ${ }^{5}$ or to place responsibility for the violation of a constitutional right where it truly belongs and achieve a correction or change in the institutional entity. Both of these are wholly justifiable and defensible given the statute's "three main aims" as articulated by Justice Douglas in Monroe v. Pape, ${ }^{6}$ to override certain state laws, to provide a federal remedy not provided by state law, and to provide a remedy "where the state remedy, though adequate in theory, was not available in practice."?

While the aims of the great statute embody both reasons, the correction of institutional or systemic problems requires proportionally greater consideration and attention as compensation can be addressed through more straightforward means. ${ }^{8}$ Further, the controlling law in this area should not impose limitations on local public entity claims because of fiscal concerns when those same limitations will seriously undermine the statute's utility to correct a systemic problem. When the public entity either created the policy that led to the violation, employed an individual policymaker who created the policy, knew or should have known of the unconstitutional practice due to its repeated occurrence, or failed to bring the particular department's practices up to an acceptable level of functioning (i.e., failure to train, discipline, etc.), ${ }^{9}$ then effecting systemic change will better society as a whole and, hopefully, reduce the number of instances leading to suits for individual compensation.

As entity liability stands now, only a Scholar Warrior can survive the contortions and convolutions inherent in the current state of the law. In accord with Professor Beermann, the Scholar Warrior has to be an historian of the law, uncovering, evaluating, and reinterpreting

5. The pursuit of the deep pocket can, itself, be for a variety of reasons, including to avoid juror sympathies that will unjustifiably curtail an award against an individual officer or to avoid the harsh outcome of no award where only the individual defendant is sued and the court grants the defendant qualified immunity.

6. 365 U.S. 167 (1961).

7. Id. at 173-74.

8. Here, indemnification statutes and insurance also guarantee that damages are paid. See, e.g., Symposium, Constitutionality of Indemnification Legislation, 9 J. SUFFolK ACAD. L. 31 (1994); Peter Cassat, Comment, Statutory Indemnification In Section 1983 Actions Based On Police Misconduct: Choosing A Forum, 1988 WIs. L. Rev. 605. To the extent that Monell claims are made to increase monetary relief beyond that which is appropriate, such situations do not merit a place in this discussion.

9. These are the four basic forms of Monell claims. 
the Court's "underdeveloped analysis of [ $\$ 1983$ 's] text and legislative history" in light of the common law background of the statute and more recent common law developments. ${ }^{10}$ Moreover, the Scholar Warrior has to "continually construct ingenious theories for holding municipalities responsible for the conduct of municipal employees." 11 Thus, the Scholar Warrior must have extensive knowledge and understanding that is free of any time period limitation and intensely creative.

Professor Gerhardt's analysis reveals that the Scholar Warrior must have the greatest of insights and foresights. First, akin to Professor Beermann, Professor Gerhardt suggests that the Scholar Warrior extend and apply basic analysis to include innovative theories, such as institutional analysis, to direct and redirect the Court's interpretations of $\S 1983$ and varieties of constitutional law. ${ }^{12}$ Further, he aptly points out that the Scholar Warrior must have the insight to know, as well as the flexibility to follow, when the Court is going to apply an individual mindset requirement on a public entity, when tort analysis will prevail, and when the Court will take another approach. ${ }^{13}$ Quite appropriately, then, Professor Gerhardt describes an ever-changing three dimensional minefield for the Scholar Warrior to negotiate, never knowing if one step will be her last or will transport her into another dimension of analysis. ${ }^{14}$ The Scholar Warrior must be deft of balance, flexible and adaptable.

Professor Blum agrees that the Scholar Warrior has to engage, unwind and apply the "highly complex body of interpretive law" in order to bring (let alone prevail in) a Monell claim. ${ }^{15}$ Using high speed chases as an exemplar, the Scholar Warrior must be keen to understand not just nuance and conflict in the law, between the circuits and within the Court's determinations, but also true confusion to which the Court itself appears blind or ignorant. ${ }^{16}$ The Scholar Warrior must be part visionary.

10. Jack M. Beermann, Municipal Responsibility for Constitutional Torts, 48 DePAul L. Rev. $627,627,629-40$ (1999).

11. Id.

12. Michael J. Gerhardt, Institutional Analysis of Municipal Liability Under Section 1983, 48 DePaul L. Rev. 669, 670, 677-85 (1999).

13. Id. at 671-76.

14. Id. (noting the immense difference between the terrain as defined by Monell and the current lay of the land).

15. Karen M. Blum, Municipal Liability: Derivative or Direct? Statutory or Constitutional? Distinguishing the Canton Case from the Collins Case, 48 DePaul L. Rev. 687, 687 (1999) (quoting Board of County Comm'rs v. Brown, 520 U.S. 397, 416-17 (1997) (Breyer, J., dissenting).

16. Id. at 688-95 (comparing direct and derivative liability). 
In addition to these impediments, the Scholar Warrior must be ready for a judge who, as Judge Hamilton states, thinks "Monell claims should be litigated and tried less often."17 While every civil rights lawyer must evaluate her case to the utmost degree possible, this may not adequately prepare the case for the new roadblocks that may arise in the form of "institutional biases-or perhaps "predispositions" "including the assumption that the pleadings are weak, that the "claims should have little practical significance" in most cases, and that the judge may desire to have only the best of Scholar Warriors appear to litigate the claims. ${ }^{18}$ Underlying these assumptions, Judge Hamilton asserts that the primary motivations for Monell claims lie in financial gain and not in societal change; thus indemnification, bifurcation, and issue preclusion will be essential judicial tools toward maintaining judicial control over Monell. ${ }^{19}$ Here, the Scholar Warrior must be a master tactician and strategist.

Mr. Taylor brings our focus squarely to $\S 1983$ suits that are aimed to change an ill-advised, ill-conceived, or ill-managed public entity design that is detrimental to the civil and constitutional rights of the civic population and society as a whole. ${ }^{20}$ By definition, a systemic problem is one that the system is incapable or unwilling to acknowledge and/or rectify. Only a court order will commence the process of change. ${ }^{21}$ Here, the Scholar Warrior valiantly defends the weaker and unrepresented in society while the entire system of the public entity is brought to bear on the litigation. ${ }^{22}$ The attitudes of the defendants and their lawyers necessitate the depth and persistence of discovery

17. Hon. David F. Hamilton, The Importance and Overuse of Policy and Custom Claims: $A$ View from One Trench, 48 DePaul L. Rev. 723, 723 (1999).

18. Id. at 727,729 .

19. Id. at 729,737 .

20. G. Flint Taylor, A Litigator's View of Discovery and Proof in Police Misconduct Policy and Practice Cases, 48 DePaul L. Rev. 747, 748-49 (1999).

21. Some assert that if the compensatory damage award or a series of such awards are significant enough, then the local public entity will start the process of change internally. This approach, however, presumes that local public entities make decisions by adequately considering such fiscal concerns and risks, that segments of local government all have equal bargaining power in this process and that such awards will not be seen, simply, as the cost of doing business. Using law enforcement as one example, this local constituency wields a great deal of power within local government and outside as well. The popular culture's perceptions of law enforcement and the ease with which changes in police rules and practices can be deemed politically sensitive or "pro-crime" changes this balance dramatically and neutralizes any potential influence of this financial impact approach.

22. Here, the simplest example is Mr. Taylor's own dealing with the torture of alleged police killers. Taylor, supra note 20, at 759-63. Absent representation of the alleged and convicted police killers, how else would the subject of police torture of suspects even get raised, let alone be addressed? 
tools that result in full battlefield engagement. ${ }^{23}$ As with all war, the tolls are high in expenses, time, and landscape, the battles are many, the observers scrutinize every strategy and tactic constantly changing their assessments of its correctness, and the participants grow weary in strength but ever stronger in their disdain for the opponent. ${ }^{24}$ Critical here is that the patterns of police torture and police domestic violence utilized by Mr. Taylor are not localized or isolated by any means. ${ }^{25}$

At the current pace of splintering in entity liability law, ${ }^{26}$ the Scholar Warrior may not survive much longer. Thus, reform is necessary now. Most cases involve law enforcement, and the systemic problems in law enforcement nationwide are monumental and growing. Problems exist in the failure to properly and adequately hire and screen, ${ }^{27}$ train, ${ }^{28}$ monitor, supervise, counsel, and discipline. ${ }^{29}$ Further, the law enforcement "Code of Silence" serves not only to make a mockery of the criminal justice system, ${ }^{30}$ but also serves as a barrier to internal law enforcement review and reform such that officers with multiple offenses remain in the system and their continued presence sustains the Code. ${ }^{31}$ Finally, persistent issues of race, sex, and homophobia-based actions by law enforcement undermine any belief

23. Id. at 749; see, e.g., Steve Mills, Attorney Wants Police Documents on Brutality Charges Made Public, CHI. TRIB., Mar. 24, 1999, $\$ 2$, at 2 (noting "city attorneys had not yet seen Taylor's motion but would likely oppose it").

24. Taylor, supra note 20, at 749; see Richard K. Neumann Jr., On Strategy, 59 Fordham L. Rev. 299 (1990).

25. Mr. Taylor references two cases arising in the Chicago area. Wilson v. City of Chicago, 6 F.3d 1233 (7th Cir. 1993) (torture); Czajkowski v. City of Chicago, 810 F. Supp. 1428 (N.D. Ill. 1992) (domestic violence). Both types of cases can be found around the country. See, e.g., Thomas v. City of New Orleans, 687 F.2d 80 (5th Cir. 1982) (upholding the firing of police officer for breaking code of silence by blowing whistle on police torture of suspects in killing of police officer); see also Michael Avery et al., Police Misconduct: Law \& Litigation $\$ 4: 20$ (collecting cases on inadequate hiring); $i d$. $\S 4: 21$ (collecting cases on inadequate training); $i d$. $\S 4: 22$ (collecting cases on inadequate supervision and discipline).

26. Seemingly, every term since Monell was decided, the Court has added to the kaleidoscope of local public entity liability. See, e.g., McMillian v. Monroe County, 520 U.S. 781 (1997); County of Sacramento v. Lewis, 523 U.S. 833 (1997); Board of County Comm'rs v. Brown, 520 U.S. 397 (1997); Farmer v. Brennan, 511 U.S. 825 (1994); Leatherman v. Tarrant County, 507 U.S. 163 (1993); Collins v. City of Harker Heights, 503 U.S. 115 (1992); Will v. Michigan Dep't. of State Police, 491 U.S. 58 (1989); Jett v. Dallas Indep. Sch. Dist., 491 U.S. 701 (1989); City of Canton v. Harris, 489 U.S. 378 (1989); City of St. Louis v. Praprotnik, 485 U.S. 112 (1988); Pembaur v. City of Cincinnati, 475 U.S. 469 (1986); City of Los Angeles v. Heller, 475 U.S. 796 (1986); City of Oklahoma City v. Tuttle, 471 U.S. 808 (1985); City of Newport v. Fact Concerts, Inc., 453 U.S. 247 (1981); Owen v. City of Independence, 445 U.S. 622 (1980).

27. See AVERy ET AL., supra note $25, \S 4: 21$.

28. See id. \$ 4:20.

29. See id. $\$ 4: 22$.

30. See id. § 11:17.

31. See id. § 4:22. 
that law enforcement serves society. ${ }^{32}$ These problems have risen beyond the level of one bad apple, one bad precinct, or one bad city such that international human rights organizations have noticed, investigated, and reported findings that align law enforcement conduct in this country with that of some of the worst human rights offenders world-wide. ${ }^{33}$

\section{The Problems with Monell and the Need for Change}

Justice Stevens has repeatedly called for the abandonment of $\mathrm{Mo}$ nell and its progeny in favor of respondeat superior liability for public entities. $^{34}$ Three additional Justices on the Court have now added their voices to Justice Stevens' in a broader call for a reexamination of the Monell legacy. ${ }^{35}$ Obviously, with five other votes remaining on the Court, any change, even imminent, could come in a variety of forms. Even before this Symposium, the calls for Monell reform have been frequent, formidable, and varied. ${ }^{36}$ These suggestions or poten-

32. On law enforcement and homophobia, see Carla M. da Luz, A Legal and Social Comparison of Heterosexual and Same-Sex Domestic Violence: Similar Inadequacies in Legal Recognition and Response, 4 S. CAL. Rev. L. \& Women's Stud. 251, 268 (1994) and James D. Wilets, International Human Rights Law \& Sexual Orientation, 18 Hastings INT'L \& CoMP. L. REv. 1, 41 (1994). On law enforcement and racism, see William J. Stuntz, Race, Class And Drugs, 98 Colum. L. Rev. 1795, 1842 n.6 (1998) (citations omitted) and William J. Stuntz, Terry's Impossibility, 72 ST. JoHN's L. Rev. 1213, $1220 \mathrm{nn} .20-21$ (1998). On law enforcement and sexism, see Sabrina Turner, Book Review, Breaking \& Entering: Women Cops Talk About Life In The Ultimate Men's Club, 11 Wis. Women's L.J. 175, 177 (1996).

33. Amnesty Int'l, United States of America, Police Brutality and Excessive Force in the New York City Police Department (1996); Human Rights Watch, Shielded From Justice: Police Brutality and Accountability in the United States (1998). The Human Rights Watch report is just short of 400 pages (without appendices) and covers 14 cities ranging from New York to Providence. The Summary and Recommendations are alone 24 pages in length covering police and prosecutors, local, state, and national government and include 63 specific recommendations for systemic reform. Id. at 11-24.

34. See, e.g., Pembaur v. City of Cincinnati, 475 U.S. 469, 489 (1986) (Stevens, J., dissenting); City of Oklahoma City v. Tuttle, 471 U.S. 808, 835-40 (1985) (Stevens, J., dissenting).

35. Board of County Comm'rs v. Brown, 520 U.S. 397, 416-39 (1987) (Breyer, J., dissenting, joined by Justices Ginsburg and Souter).

36. See Jack M. Beermann, A Critical Approach to Section 1983 with Special Attention to Sources of Law, 42 StAN. L. Rev. 51, 76-101 (1989); Steven Stein Cushman, Municipal Liability Under Section 1983: Toward a New Definition of Municipal Policymaker, 34 B.C. L. Rev. 693, 723-29 (1993) (offering alternative construct on policymaker); Larry Kramer \& Alan O. Sykes, Municipal Liability Under Section 1983: A Legal and Economic Analysis, 1987 Sup. Cт. Rev. 249, 294-301; Harold S. Lewis \& Theodore Y. Blumoff, Reshaping Section 1983's Asymmetry, 140 U. PA. L. Rev. 755, 829-50 (1992) (arguing for respondeat superior); Susanah Mead, 42 U.S.C. $\$ 1983$ Municipal Liability: The Monell Sketch Becomes a Distorted Picture, 65 N.C. L. Rev. 517, 538-42 (1987) (same); Peter H. Schuck, Municipal Liability Under Section 1983: Some Lessons From Tort Law and Organization Theory, 77 Geo. L.J. 1753 (1989) (arguing for respondeat superior); Barbara Rook Snyder, The Final Authority Analysis: A Unified Approach to Municipal Liability Under Section 1983, 1986 WIS. L. REv. 633, 646-76 (offering alternative construct on 
tial outcomes can be categorized as retrograde (a return to only $\mathrm{Mo}$ nell or Monroe), tinkering (some change to the current state of the law), and abandonment (utilizing some tool other than Monell to ensure public entity liability).

The retrograde approach would eliminate recovery against local public entities or limit such recovery to a finite number of situations. Monell only supported public entity liability with a "policy statement, ordinance, regulation, or decision officially adopted and promulgated by that body's officers" or a "governmental custom . . . so permanent and well settled as to constitute a 'custom or usage' with the force of law." 37 In a society where government officials know better than to formalize or reduce such decisions to a form that could be discovered in a paper trail, the likelihood of written policies is very limited. It is also uncertain how the Court would determine "custom or usage" under such a more limited perspective. ${ }^{38}$ While the current the standard allows litigation against egregious systemic harms, the potential exists that such systemic harms could be further sheltered from review and correction through litigation. Under this approach, the Scholar Warrior would be even more challenged in attempting to eradicate systemic problems.

Tinkering, perhaps more aptly labeled warping, has led to the current state of the law. In addition to the difficulties in this approach apparent from the presentations by Professors Beermann, Gerhardt, and Blum, several other problem areas exemplify the future of this path. Although $\S 1983$ was enacted because state and local lawmakers and law enforcement officials were not enforcing laws or not enforcing them fairly, ${ }^{39}$ a state can now convert local officials into state officials and effectively eliminate local public entity liability for their actions. ${ }^{40}$ In addition, the hunt to determine who is a local policymaker must pass through state law. ${ }^{41}$ This elevation of state law to its current level of importance is antithetical to the critical, original purpose of $\S 1983$

policymaker); Christina B. Whitman, Government Responsibility For Constitutional Torts, 85 Mich. L. REv. 225, 234-48, 254-57 (1986).

37. Monell v. Department of Soc. Servs., 436 U.S. 658, 690-91 (1978).

38. There is a range of definitions on this. See, e.g., Eric Schnapper, A Monell UpdateClarity, Conflict and Complications, in 5 Section 1983 Civil Rights Litigation ANd ATtorNey Fees Annual Handbook 55, 60-61 (1989).

39. See, e.g., Robert J. Kaczorowski, Federal Enforcement Of Civil Rights During The First Reconstruction, 23 Fordham URB. L.J. 155, 158-69 (1995); Robert J. Kaczorowski, Revolutionary Constitutionalism In The Era Of The Civil War And Reconstruction, 61 N.Y.U. L. Rev. 863, 874-84 (1986).

40. McMillian v. Monroe County, 520 U.S. 781, $783-96$ (1997).

41. Jett v. Dallas Indep. Sch. Dist., 491 U.S. 701,737 (1989) (O'Connor, J., majority opinion); City of St. Louis v. Praprotnik, 485 U.S. 112, 123 (1988) (O'Connor, J., plurality opinion). 
to override actions taken "under color of" state law that led to constitutional violations, as opposed to looking for state law approval for those actions prior to a determination of liability. ${ }^{42}$ The Scholar Warrior has slogged through this field, but may not be able to withstand all the future permutations. ${ }^{43}$

One can surmise from the presentations that our Symposium participants favor abandonment of Monell, though not necessarily for the same reasons. ${ }^{44}$ According to Professor Beermann, the current state of the law is an incorrect interpretation of the legislative history and the historical context of the passage of $\S 1983 .{ }^{45}$ In his presentation, fairness, judicial efficiency, avoiding needless complications, and the original purpose of the statute all countenance implementation of respondeat superior instead. ${ }^{46}$ Professor Gerhardt agrees that the current state is not fair and does not adequately hold an institution responsible where it did not act maliciously but, nevertheless, caused the harm due to its structure, decisionmaking, or gaps in rules or communication. ${ }^{47}$ Finally, Mr. Taylor ardently supports respondeat superior. ${ }^{48}$ How the Scholar Warrior will fare under this last possibility requires greater attention.

\section{The Need for Respondeat SuPERIOR "Plus"}

Any new paradigm for $\S 1983$ must further the original aims, as articulated in Monroe, and be a viable tool to address and rectify systemic problems. Section 1983 must provide a meaningful, attainable and effective remedy for civil rights violations that emanate from a

42. McMillian, 365 U.S. at 184-87; see Steven L. Winter, The Meaning Of "Under Color Of" Law, 91 Mich. L. REv. 323, 404-07 (1992).

43. My limited presentation here has not even touched upon the problems faced by the Scholar Warrior from the standpoint of federalism, state of mind, causation, and qualified immunity issues. See, e.g., Peter W. Low \& John C. Jeffries, Jr., Civil Rights Actions: Section 1983 and Related Statutes 658-60, 713-15 (1994) (collecting articles on abstention); Alan K. Chen, The Burdens of Qualified Immunity: Summary Judgment and The Role of Facts in Constitutional Tort Law, 47 AM. U. L. Rev. 1, 4 n.14 (1997) (discussing qualified immunity and collecting other articles); Barbara Kritchevsky, Making Sense of State of Mind: Determining Responsibility in Section 1983 Municipal Liability Litigation, 60 Geo. WASH. L. Rev. 417, 423-40 (1992) (same); Barbara Kritchevsky, "Or Causes to Be Subjected": The Role of Causation in Section 1983 Municipal Liability Analysis, 35 UCLA L. Rev. 1187, 1198-1227 (1988) (discussing causation); Barbara Kritchevsky, Return to Owen: Depersonalizing Section 1983 Municipal Liability Litigation, 41 VILL. L. Rev. 1381, 1387-1415 (1996) (discussing state of mind).

44. While Professor Blum's presentation, to some extent, looks for resolution or hope in the Court's reworking of its doctrine, her aim here was more on practicalities of the current state than alternative approaches. Blum, supra note 15 , at 688 .

45. Beermann, supra note 10 , at 665-68.

46. Id.

47. Gerhardt, supra note 12 , at $685-86$.

48. Taylor, supra note 20 , at 771-72. 
local public entity. Two other considerations bear mention and are easily incorporated. Local public entities would seek some accounting for the variety of their natures. Further, the courts would manage best with a simple test, particularly one that can be applied without the potential for reinventing Monell and its progeny.

Can respondeat superior alone accomplish all of these goals and address all of these interests? Certainly, respondeat superior is generally consistent with the aims of the statute. ${ }^{49}$ Further, in tort litigation, it has proven quite consistent with local public entities of all sizes, shapes, structures, and locations, regardless of decision-makers, financial liquidity, or other concerns that have arisen in $\$ 1983$ litigation. ${ }^{50}$ Respondeat superior has been a workable judicial tool as well. ${ }^{51}$ If there is a shortfall in this test, it is only that it addresses some, but not all, of $\S 1983$ 's concerns.

Civil rights enforcement needs strength, thus and any doctrine used to achieve this goal must, likewise, have "teeth." Respondeat superior needs such "teeth." Past decisions of the Court have eviscerated the Scholar Warrior's ability to use $\S 1983$ to effect systemic change by dramatically limiting standing 52 and eliminating aspects of injunctive relief. ${ }^{53}$ Only with the return of these tools can the Scholar Warrior effectively address systemic problems that cause constitutional violations. ${ }^{54}$

49. See, e.g., Beermann, supra note 10 , at 644,651 ; Lewis \& Blumoff, supra note 36 , at 829-50.

50. Here, municipalities have all of the usual tort defenses, i.e. frolic and detour, to deal with situations that would not otherwise have been traceable to the public entity. See, e.g., Stuart M. Speniser et Al, The American Law of Torts $\$ \$ 4: 13-4: 20,17: 51$ (1988) (outlining the variety of issues that can be raised by the defendant to respondeat liability).

51. There is no comparable body of articles or opinions criticizing the blossoming cottage litigation, interlocutory appeals, or vexing complications in tort law. Many of the rulings that alter the framework of tort litigation impact in exactly the same way in civil rights litigation. For instance, the recent machinations of Federal Rules of Evidence 702, affect both types of cases insofar as they utilize experts. See Kumho Tire Co. v. Carmichael, 1999 WL 152455 (S. Ct. Mar. 23,1999 ) (examining the requirements for expert witnesses and their testimony and concluding "that Daubert's general holding - setting forth the trial judge's general 'gatekeeping' obligation-applies not only to testimony based on 'scientific' knowledge, but also to testimony based on 'technical' and 'other specialized' knowledge"). Thus, tort law does not seem to suffer from the same evolutionary forces as civil rights law. See supra note 26 and accompanying text.

52. City of Los Angeles v. Lyons, 461 U.S. 95 (1983) (holding an African-American man has no standing to challenge systemic use of chokeholds against African-American men stopped by Los Angeles police due to an inability to assert a likelihood of recurrence).

53. Rizzo v. Goode, 423 U.S. 362 (1976) (overturning injunction requiring city to draft comprehensive police plan for handling misconduct complaints due to limited number of complaints and police involved).

54. Seth F. Kreimer, Exploring The Dark Matter Of Judicial Review: A Constitutional Census Of The 1990s, 5 WM. \& MARY BILl RTs. J. 427, 501 n.172 (1997) ("Unfortunately, since [Rizzo and Lyons] the obstacle of finding a plaintiff who is currently subject to the challenged practice has proved an almost insurmountable barrier to prospective relief in most police cases."); 
However, only limited avenues exist by which the adoption of respondeat superior and the return of meaningful injunctive relief can be had. The Court's history does not predict swift, broad, or effective judicial change in favor of $\S 1983$ becoming a tool for addressing systemic problems. Likewise, the path of economic force, that is obtaining monetary judgments and waiting for the municipality to change its policy as a result, has been tried and failed to lead to effective resolution. ${ }^{55}$ Thus, court decisions leave local public entities secure in believing that, in many instances, change is unnecessary and, when necessary, only reactive measures are sufficient.

In its study of the institutional nature of police brutality in this country, Human Rights Watch reached several recommendations for changes in the legal paradigm. ${ }^{56}$ These changes include a greater federal government presence and role in investigation and prosecution of police brutality. ${ }^{57}$ The federal-level recommendations include changing legal standards, increasing funding to the Civil Rights Division of the Justice Department and legislation implementing the several international agreements, making torture (no matter who commits the act) a federal crime, and conditioning federal law enforcement money on adequate and independent civilian oversight and review commissions. ${ }^{58}$ The state-level recommendations include the creation of state offices dedicated to prosecuting police officials who skirt the law, state oversight and investigatory units, and independent local investigatory units with the power of subpoena. 59

Critical to this success is requiring institutional change in a proactive, as opposed to reactive, manner. Thus, local public entities should be required to, and rewarded for, reviews, the implementation of

Christina Brooks Whitman, Emphasizing The Constitutional In Constitutional Torts, $72 \mathrm{CH}_{\mathrm{H}}$. KENT L. Rev. 661, 671 (1997)("Standing and proof problems could be insurmountable barriers even if suit were brought in a location where official lawlessness was widespread and targeted at a specific population."); see Richard H. Fallon Jr., Of Justiciability, Remedies, And Public Law Litigation: Notes On The Jurisprudence Of Lyons, 59 N.Y.U. L. Rev. 1, 13-74 (1984); Linda E. Fisher, Caging Lyons: The Availability Of Injunctive Relief In Section 1983 Actions, 18 LoY. U. CHI. L.J. 1085, 1086-1117 (1987); Paul Hoffman, The Feds, Lies, and Videotape: The Need for an Effective Federal Role in Controlling Police Abuse in Urban America, 66 S. CAL. L. Rev. 1453, 1504-28 (1993); Michael J. Schmidtberger, No Holds Barred In City of Los Angeles v. Lyons: Standing To Seek Injunctions In Federal Court Against Municipalities, 15 Colum. Hum. RTs. L. Rev. 183, 192-205 (1984); Alison L. Patton, Note, The Endless Cycle of Abuse: Why 42 U.S.C. Section 1983 Is Ineffective in Deterring Police Brutality, 44 HAstings L.J. 753, 802-07 (1993).

55. See supra note 21 and accompanying text.

56. Human Rights WATCH, supra note 33, at 10-24 (providing summary of recommendations).

57. Id. at 11-12, 14-15, 20-23.

58. Id.

59. Id. at 12-14. 
change, and the weeding out of bad actors. ${ }^{60}$ These systemic changes should be conceived and implemented to remove obstacles to justice and to obtain and maintain public accountability and transparency or visibility. ${ }^{61}$ While many law enforcement organizations have advocated the adoption of new or national standards for policing after Supreme Court decisions or without the force necessary for national adoption, ${ }^{62}$ perhaps these groups will find greater foresight and reception when positive change is linked with federal financial assistance or other rewards.

This necessitates considerable dedication and effort from Congress and the executive branch. Recently, Congress did enact legislation permitting the Department of Justice to obtain injunctive relief against local public entities for systemic problems. ${ }^{63}$ The power of this new statute is evidenced by the Consent Decree entered between the City of Pittsburgh and the Department of Justice in 1997.64 The extension of this statute to private individuals would effectively overrule Rizzo and Lyons and add the "teeth" needed to address systemic problems. When combined with the Human Rights Watch recommendations, the Scholar Warrior will have the tools necessary and worthy of her task.

\section{CONCLUSION}

The Scholar Warrior symbolizes both what is right and what is wrong with the current Court interpretation of $\S 1983$. She represents the litigator who can succeed under the current construct of law and

60. Id. at 14-20.

61. Id. at 21-24.

62. See, e.g., Samuel Walker \& Lori Fridell, Forces of Change in Police Policy: The Impact of Tennessee v. Garner, 11 Am. J. of Police 97, 101 (1992).

63. The text of the statute is as follows:

(a) Unlawful conduct

It shall be unlawful for any governmental authority, or any agent thereof, or any person acting on behalf of a governmental authority, to engage in a pattern or practice of conduct by law enforcement officers or by officials or employees of any governmental agency with responsibility for the administration of juvenile justice or the incarceration of juveniles that deprives persons of rights, privileges, or immunities secured or protected by the Constitution or laws of the United States.

(b) Civil action by Attorney General

Whenever the Attorney General has reasonable cause to believe that a violation of paragraph (1) has occurred, the Attorney General, for or in the name of the United States, may in a civil action obtain appropriate equitable and declaratory relief to eliminate the pattern or practice.

42 U.S.C. $\$ 14,141$ (1994).

64. See G. Flint Taylor, U.S. Government Obtains Pittsburgh Consen't Decree, 5 Police Misconduct \& Civil RTs. Law Rep. 114 (1997). 
the one who will be most likely to survive any future derivations. She also stands for the limited nature of those who can effectively utilize $\S 1983$ and the problem with the statute being out of reach for many litigators who have equally valid claims addressing local public entity actions.

The substitution of respondeat superior for Monell and its progeny is a huge step in the right direction. However, if $\S 1983$ is to be the tool in the civil rights litigator's arsenal for addressing, attacking, and changing systemic problems in local public entities, then any change must include not only respondeat superior, but also the ability to obtain injunctive relief.

The Scholar Warrior represents a key image in this field as one looks to the future application of $\S 1983$. The Scholar Warrior represents balance, "a cohesive approach, organized through the dualities of mental and physical, quiescent and active, refined and coarse" that reflects an equilibrium. ${ }^{65}$ This balance is good for the civil rights litigator and the benefits would extend to the legal system and society in which she works. 